\title{
青壮年変股症に効する観血的治療の種々の試み
}

九州大学医学部 整形外科
西 尾 篤 人・杉 岡 洋 一
北 島 俊 裕. 柴 田 堅一郎
松 永 大 助・西 嶋 壮 夫

\section{Cup to Socket Arthroplasty of the Hip}

By

\author{
A. Nishio, Y. Sugioka, T. Kitajima, \\ K. Shibata, D. Matsunaga \& T. Nishijima \\ Department of Orthopedic Surgery, \\ Kyushu University
}

わが国の変形性股関節症は二次性の, とくに先天性 股関節脱臼に続発するものが多く，その発生防止に初 期治療はもちろん, 严脱臼位による機能障䈍を最小限 度にとどめた目蓋移動術と亜脱臼に対し下肢の短縮, 股関節部の変形, トレンデレンブルグ跛行のおてらな いように転子部彎曲状内反骨切り術を考案し行なって きた。しかし先天股脱の股関節のレ線変化を追究する と 30 才を過ぎると年とともに急激に関節端の変性と 疼痛が強くなり支持性と可動性とが急速に失なわれて 行く.その上先天性股関節脱曰では両側性のものが多 く, それらのものを如何に治療するか重要な問題であ る. 変性に陷った変形の強い股関節に各方向への無痛 性の運動を得させることは容易でない. 最近の全人工 股関節置換術の成績は股関節の疼痛を解放し, 優秀な 可動性と支持性を得させる極めて優れた方法である が，耐用性の問題から青壮年患者に適用できない。わ が国の変股症患者の多くは壮年時代から高度の障害を 訴えるものが多く治療に困惑させられる.

変形性股関節症では 青壮年者には骨切り術や Cup arthroplasty を老年者には全人工関節置換術が多く 行なわれている. Cup arthroplasty の成績は長期間 良好な可動性と無痛の支持性を得るものもあるが, 成 績が一定しないととと長期間の熱心な後療法が必要で ある.Cup が内反位になったり，Cup と頭骨との間 の可動性が障害されると疼痛が発生し可動性か支持性 が失なわれる. Cup も Smith-Petersen 型の ecce- ntric のものと Adams 型の concentric type のも のがあり, eccentric type のものは股関節の運動に 不自然なところがあり, concentric typeのものは寛 骨臼とCup の間の可動性が制限されてくると大腿骨 頭部に剪力が働き障害がおてっている。

全人工関節置換術の手術適応年令は 65 才以上と考 えられているが，てれまでの期間機能障害を改善さ せ, 若し手術後障害がおてれば関節固定術や全人工関 節置換術にかえるととができる方法として Cup と Socketによる人工股関節形成術を考案した.

青壮年の変形性股関節症の障害の著しいもの, とく に両側性のものに無痛の可動性を得させるためCup arthroplasty の欠点を除き筧骨臼にセメントを使用 せず Urist 型の 3 本の足のついた Socket を固定し, concentric type の Cup に頸部をつけたものを大腿 骨頭と頸部にかぶせて Cup と Socket の間で十分な 可動性を保たせる金属の Cup と Socket による人工 関節形成術を行なった。

全身麻醉の下に側臥位で腸骨前上棘から大転子直下 を通り腎部に及ぶ弓状切開, 筋膜と大鋳筋の一部を切 り大転子を出す．大転子を切り中，小篮笳とともに翻 転して関節包を出す. 後方は外旋筋の一部を切り, 関 節包の前方, 側方, 後方を十分に展開し, 関節包を切 除し, 股関節を屈曲, 内転, 外旋して股関節を脱白さ せ関節包の内側を切断する. 大腿骨頭を骨盤に対して 十分遊離し，寛骨曰をノミとリーマーで Socket に合 

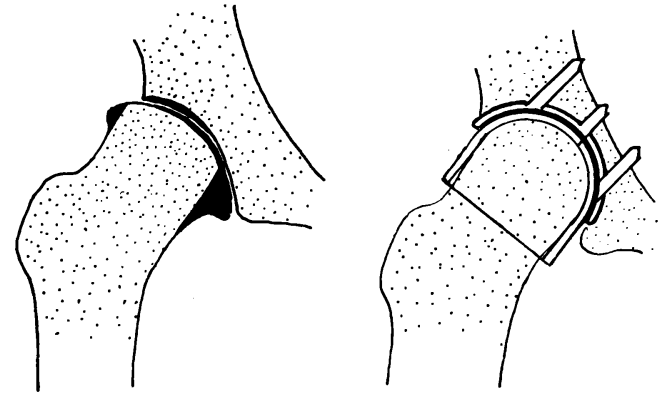

第1図 Cup to socket 股関節形成術

せで掘る．特に内下方に，白を作製するように努力す る. 次に大腿骨頭および頸部を頸体角 $140^{\circ}$, 前捻が 強くならず骨頭と頸部の外上方の丈夫な海綿骨が残る ようにノミと頸部用のリーマーで骨頭と頸部を作る.

Socket をできるだけ水平面に $40^{\circ}$ 近くなるように Socket の 3 本の足を打ち込む. 3 本の足の位置に予 め穴をあけておくと容易である. 先天性股関節脱曰に よる変形性股関節症が多いため臼蓋の形成不全を伴な うものには Socket が四蓋ではみ出すものが多く, 腸 骨骨片を曰蓋に移植し螺子で固定するか, Socket と 曰蓋の骨欠損部に少量の骨セメントを入れて固定す る. 大腿骨頭の軟骨下骨梁は硬く Cup の固定にはよ いが，骨頭にかかる圧力が術前よりも増加し，下肢長 もかえってながくなる傾向があり，できるだけ肥厚し た骨梁を残して一部切除して大腿骨頭および 頸部に Cup を打ち込む. Cup の内側は円滑に磨かれてお り，骨吸収が少しおこれば内外旋をCup と骨頭との 間でとめることはできないが，骨の消耗を防ぐために はよいと考えている．整復後股関節の可動性を確め大 転子縫合, 筋膜, 皮膚縫合, ドレーンは $2 \sim 3$ 日留置 する. 術後股関節を体展位にして軽く介達率引を行な い2 週後から自動運動を開始する. 2 〜 力月は杖を 使用させ全荷重は許さない。

全人工関節置換術との相違は大腿骨頭および頸部を 残すために Cup の頸部が太くなり Cup と Socket の物理的の可動性は屈伸, 内外転では最高 $80^{\circ}$ に制限 されているととと, 原則として骨セメントを使用せず 将来障害がおこれば股関節固定術や全人工関節置換術 の可能性を残したてとである.

本法を 41 例 (44 関節) に行なった. 先天股脱後の 変形性股関節症が 26 例で最も多く, 特発性大腿骨頭 壊死, 関節りウマチ, 外傷性のものがこれに続く.

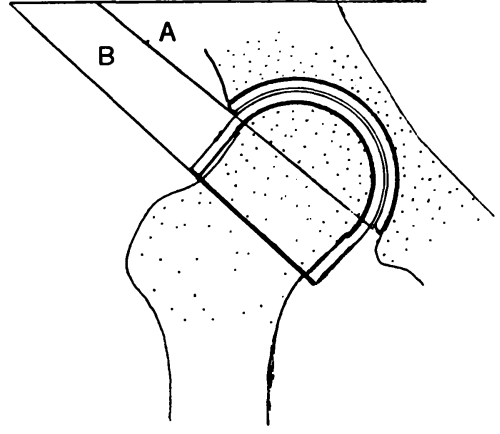

第2図 A : Socket の傾斜角度 B : Cup の傾斜角度

年令別にみると 40 才代 11 例, 50 才代 10 例で若年 者の 20〜30才代が 15 例にみられるととであり， 65 才以上は原則として全人工関節置換術を行なってい る.

両側に行なったものが 3 例である．若年の偏側性の ものには関節固定術を原則としているが, 疼痛が強い にも拘らず可動性が残されているものには患者の希望 によって本法を行なつたものもある。

本法を行ない最長 3 年の経過をみたにすぎないので 成績を十分に判定できる段階ではないが，良好な無痛 の可動性を得たものが多く支持性も良好であり，Cup arthroplasty と比較して成績が一定しており，特に 心配していた Socket の loosening は 1 例のみであ る. この例では Socket のみならず Cup も loose になり, 関節内に黒色の金属の粉末が多量に沈着し, 金属と骨との間にはやわらかい肉芽が允満していた。 軽微の感染によるものかとも考えたが, もちろん細菌 培養は陰性で金属粉による hypersensitivity が原因 とも考えられる. また特発性大腿骨頭壊死に対して行 なったうち 1 例は良好な成績であったが術後 2 年 6 力 月で疼痛がおこり, 可動制限が強くなった．再手術で 金属の摩耗が強くCup と Socket の間で可動性が消 失していた。Cup をとりかえ良好な可動性を得た。 Cup と Socket に使用している金属は C. O.P. で, Vitallium に較へ Cobalt が少ないかわりに Nickel や鉄分が多く, 硬度も時に一定しないてともあり摩耗 が強く発生したのではないかと考え, 金属をさらに改 良する必要を痛感する。

骨頭荷重部を切除せず頸部が長すぎ Cup が少し内 反位になった 1 例は骨頭の一部を切除し Cup を頸部 にかぶせて疼痛もなくなった。 
Socket の傾斜は平均 $47^{\circ}$ で Urist の 50〜 70 に 較べると水平位に近いが，Cup と Socket とが同程 度の傾斜が適当であり，しかも骨頭にかぶせる Cup は内反位にならない方が望ましい. Socket の傾斜を 小さくしようと思えば臼蓋の間に間隙ができる傾向が あり，全人工関節置換術における蓋と同様の問題が 残る.

特発性大腿骨頭壊死の症例で壊死巣を如何にすべき か問題があるが，壊死栄が硬化したままであればその まま残して Cup をかぶせている.Cup と Socketの 間で可動性がなくなった再手術例の所見では壊死笨は そのまま残っており，Cupの頂点をしっかり支えてい た.

1 例に股関節が良好な可動性を有し，金属と骨の間 に loosening が認められないにも拘らず歩行時疼痛 が残存している. Cup arthroplasty で可動性が良好 であるにも拘らず説明のできないidiopathic painful cup arthroplasty の報告があるが，経過を観察して いる.

先天性股関節脱臼後の変形性股関節症は比較的若い 時代から高度の障害をおしし，特に両側性の場合は如 何に治療すべきか日常にわれわれの遭遇する大きな問 題である. 関節端の破壊変性が強いと骨切り術の効果 もあまりなく，また Cup arthroplasty も一定の良 好な成績をおうめることは困難である. 全人工関節置 換術の早期の成績は優秀であり, 他に得難い利点があ るが耐用年数や salvage operation に問題があり現 在 65 才以上に用いるべきであると考えられている.
私達は青壮年の変性の強い股関節症に Cup arthroplasty と全人工関節置換術の中間的な治療法として Cup と Socket による股関節形成術を考え, 初期の 成績は良好であり，手術法，使用金属，後蹽法に改良 を行なえば十分に使用に耐える手術法と考え，成績に 検討を加えながらより完全な治療法へ発展させたい。

質 問 北里大学 真角 昭吾

(1) 骨頭壊死に Cup \& Socket をする場合, 骨頭 壊死部をそのままにして Cup をかぶせると, 頸部へ のくい込みがおこらないか.

(2) 回転骨切り術を initial stadium から advanced〜severe stadium までの症例に行なわれている ようですが，“変形骨頭”を回転させるについては関 節適合性の点で問題があると思う.

手術適応を如何に考えられていますか.

回答 九大整形 西尾 篤人

(1) 大腿骨頭壊死の再手術例でみても，特にCup のくい込みが強く発生する傾向はみられなかった.

(2) 回転骨切り術の適応について 九大整形 杉岡 洋一

壊死巣が広範囲で, 新荷重関節面となるべき, 後方 関節面が温存されていないものはもちろん適応ではな いが, Collapse の程度が強くても Lauen-stein 肢 位撮影で, 壊死巣が関節面の $2 / 3$ を越えないものは, 回転後十分な関節適合性を獲得する. 